\title{
PEMIDANAAN BAGI PELAKU TINDAK PIDANA PERKOSAAN TERHADAP PENYANDANG DISABILITAS
}

\author{
A.A. Kompiang Dhipa Aditya, I Nyoman Gede Sugiartha, Ni Made Sukaryati Karma \\ Fakultas Hukum, Universitas Warmadewa, Denpasar-Bali, Indonesia
}

\begin{abstract}
Abstrak
Penyandang disabilitas merupakan seorang yang memiliki kekurangan baik pada fisik, intelektual, mental, atau pada sensorik sehingga dalam menjalani kehidupannya mereka mengalami hambatan, tidak seperti orang pada umumnya. Penyandang disabilitas juga kerap mendapatkan perlakukan kurang baik dalam masyarakat baik itu perlakuan diskirminatif maupun tindak pidana, salah satunya tindak pidana perkosaan. Sayangnya, sanksi pidana bagi pelaku tindak pidana perkosaan terhadap penyandang disabilitas di Indonesia belum diatur secara tegas. Bertolak dari fenomena tersebut, penelitian ini mengkaji perlindungan terhadap para penyandang disabilitas sebagai korban tindak pidana perkosaan dan sanksi bagi pelaku tindak pidana perkosaan terhadap penyandang disabilitas. Untuk mencapai tujuan ini, penelitian ini dilakukan menggunakan metode penelitian hukum normatif dengan pendekatan konseptual dan pendekatan kasus. Perlindungan terhadap para penyandang disabilitas terdapat dalam Pasal 3 dan Pasal 5 ayat (2) Undang-Undang Nomor 8 Tahun 2016 yang mana mengatur mengenai hak-hak dan perlindungan hukum bagi para penyandang disabilitas sebagai korban tindak pidana. Perlindungan terhadap korban perkosaan berbentuk restitusi dan bantuan rehabilitasi. Sanksi pelaku tindak pidana perkosaan terhadap penyandang disabilitas belum diatus secara khusus. Dalam KUHP tindak pidana perkosaan diatur secara umum, yakni dalam Pasal 285, 286, 287, 288. Dengan demikian, perlindungan hukum bagi penyandang disabilitias bertujuan untuk menjaga dan memelihara penyandang disabilitas dari tindak pidana perkosaan. Dalam Putusan Kasasi Nomor 736K/PID/2013 PN Cn sanksi bagi pelaku tindak pidana perkosaan terhadap penyandang disabilitas ialah penjatuhan sanksi dalam ketentuan Pasal 285 KUHP.
\end{abstract}

Kata Kunci: Disabilitas; Pemidanaan; Pemerkosaan

\begin{abstract}
Persons with disabilities refer to people who have physical, intellectual, mental, or sensory deficiencies so that in living their lives they find hindrances, as an opposite to normal people. Oftentimes the persons with disabilities receive poor treatment in society, be it discriminatory treatment or criminal acts, one of which is rape. Unfortunately, criminal sanctions for perpetrators of rape against persons with disabilities in Indonesia have not been explicitly regulated. Grounded with this phenomenon, this study examines the legal protection for persons with disabilities as victims of the criminal act of rape and sanctions for the perpetrators of the said criminal acts. To achieve these goals, this study was conducted using a normative legal research method with a conceptual approach and a case approach. Legal protection for persons with disabilities is contained in Article 3 and Article 5 Paragraph (2) of Law Number 8 of 2016 which regulates the rights and legal protection for persons with disabilities as victims of criminal acts. Protection for the rape victims takes the form of restitution and rehabilitation assistance. Sanctions for the perpetrators of the criminal act of rape against persons with disabilities have not been regulated strictly. In the Criminal Code, the criminal acts of rape are regulated in general sphere that is in Articles 285, 286, 287, 288. Thus, the legal protection for persons with disabilities aims to safeguard and maintain the persons with disabilities from the criminal acts of rape. In the Cassation Decision Number 736K/PID/2013 PN Cn, the sanction for perpetrators of rape against persons with disabilities is the imposition of sanctions in the provisions of Article 285 of the Criminal Code.
\end{abstract}

Keywords: Disability; Criminalization; Rape

\section{PENDAHULUAN}

Perkosaan merupakan suatu perbuatan yang sangat tidak bermoral dan melanggar hukum dan yang kerap menjadi korban adalah perempuan. Tindakan tersebut sangatlah mengancam kaum perempuan dimana harga diri dan kehormatan perempuan menjadi taruhannya. Tindak pidana perkosaan 
merupakan tindakan yang bertentangan dengan norma kesusilaan dan Hak Asasi Manusia (HAM) yang sangat merendahkan perempuan.

Perempuan yang menjadi korban perkosaan tidak memandang baik itu perempuan dewasa maupun peremuan yang masih berada dibawah umur, bahkan wanita dalam keadaan cacat fisik ataupun mental juga menjadi korban perkosaan. Perempuan dalam keadaan cacat fisik maupun mental tergolong kedalam penyandang disabilitas (Hamzah, 2015: 171). Setiap orang yang memiliki kekurangan dalam tubuh seseorang yang cukup lama sehingga menghambat seseorag tersebut untuk berinteraksi dalam lingkungannya disebut dengan Penyandang disabilitas.

Perlindungan terhadap seseorang disabilitas termuat dalam Undang-Undang Nomor 8 Tahun 2016 tentang Penyandang Disabilitas. Pelaku tindak pidana perkosaan penyandang disabilitas sering merupakan orang terdekat yang terdapat dari lingkungan sekitar korban berada terdiri dari kenalan korban, rekan korban, seseorang yang bertempat tinggal dekat dengan korban, hingga kerabat korban. Mereka beranggapan bahwa perempuan penyandang disabilitas memiliki kelemahan sehingga tidak sanggup untuk melakukan perlawanan. Meskipun perlindungan hukum terhadap penyandang disabilitas sudah ditetapkan tidak semata-mata mengurangi tingkat kejahatan terhadap penyandang disabilitas, justru makin banyak kejahatan perkosaan yang terjadi.

Mengenai sanksi terhadap pelaku pemerkosa penyandang disabilitas haruslah diberikan penegasan agar memberikan efek jera terhadap pelaku misalnya dengan pemberatan atau penambahan masa hukumannya. Kaitannya dengan hal tersebut diatas jika terjadi tindakan perkosaan terhadap disabilitas seperti salah satu contoh kasus tindak pidana perkosaan terhadap seorang wanita yang telah mengalami kecacatan dibagian fisik sehingga tidak bisa berjalan dan mengalami keterbelakangan mental, yaitu kasus yang telah diputuskan oleh Pengadilan Negeri Cirebon dengan Putusan Kasasi Nomor 736 K/PID/2013. Terkait masalah seorang terdakwa atas nama Yuswadi alias Pepen Bin Samaun telah melakukan pemerkosaan terhadap seorang wanita yang bernama Mimin yang dimana memiliki kecacatan dibagian fisik sehingga tidak bisa berjalan dan mengalami keterbelakangan mental, hanya bisa melakukan aktifitas sehari-hari di tempat tidurnya saja.

Kajian terhadap kaum tidak pidana terhadap kaum disabilitas telah banyak dilakukan sebelumnya dari berbagai pendekatan, sudut pandang, dan tujuan. Sebuah kajian mengungkap bahwa advokasi terhadap korban kekerasan difabel ditangani oleh berbagai pihak, termasuk LSM dan penegak keamanan namun sering berhenti karena berbagai kendala (Malinda dkk., 2014). Perlindungan hukum kepada difabel belum diatur secara eksplisit tetapi legal power yang ada di dalam konstitusi Indonesia telah menuju ke arah itu dan diperlukan penjelasan secara spesifik dari undang-undang sektoral (Alfian, 2015). Terkait tindakan pidana perkosaan terhadap anak juga dapat dikaji dari sudut pandang hukum positif dan hukum pidana islam (Wahyuni, 2016). Sebagai manusia dan warga Negara, penyandang disabilitas patut diperlakukan sama, memeliki hak-hak yang sama dengan warga Negara yang hidup normal secara fisik, sehingga penegak hukum perlu mencari solusi penerapan pemberian hak yang sama (Nurhayati, 2016). Tindak pidana pemerkosaan terhadap penyandang disabilitas dapat disebabkan oleh adanya subordinasi antara pelaku dan korban yang beranggapan bahwa pelaku merasa lebih kuat (Ayu, 2019). Dengan kata lain, kelemahan fisik penyandang disabilitas dimanfaatkan oleh orang-orang normal yang tidak bertanggung jawab.

Berdasarkan dengan latar belakang masalah yang telah diuraikan, masalah penelitian ialah: 1) Bagaimana perlindungan hukum terhadap penyandang disablilitas sebagai korban tindak pidana perkosaan? 2) Bagaimana sanksi pidana terhadap pelaku pemerkosaan penyandang disabilitas? Selain itu, tujuan penelitian ini adalah untuk mengungkap perlindungan hukum terhadap penyandang disabilitas sebagai korban tindak pidana perkosaan dan menelaah sanksi pidana terhadap pelaku pemerkosaan penyandang disabilitas.

\section{METODE PENELITIAN}

Tipe penelitian ini merupakan penelitian hukum normatif oleh karena pengkajiannya dilakukan melalui studi kepustakaan yaitu menelaah bahan-bahan hukum karena penelitian hukum yang digunakan yaitu normatif maka dari itu pendekatan masalah yang digunakan dalam penulisan penelitian ini merupakan pendekatan terhadap perundang-undangan, pendekatan konseptual, dan juga pendekatan kasus.

Adapun beberapa sumber bahan hukum yang digunakan dalam penelitian ini yaitu berupa: 
1. Bahan Hukum Primer

Sumber bahan hukum primer yang terdiri dari bahan hukum yang berupa perundang-undangan dan juga keputusan-keputusan oleh hakim yang berkekuatan hukum tetap.

2. Bahan Hukum Sekunder

Bahan hukum sekunder merupakan bahan-bahan hukum yang diperoleh dari pengkajian kepustakaan dengan cara membaca buku-buku hukum, jurnal-jurnal hukum, dan juga informasi elektronik yang berkaitan dengan permasalahan yang dibahas dalam penelitian ini.

3. Bahan Hukum Tersier

Bahan hukum tersier merupakan bahan hukum yang diperoleh dari pengkajian beberapa kamus hukum, ensiklopedia dan beberapa bahan hukum yang berkaitan dengan permasalahan dalam penelitian ini.

Teknik pengumpulan bahan hukum yang digunakan dalam penelitian ini berupa teknik studi dokumentasi, pencatatan, meringkas, atau mengulas informasi baik dalam buku-buku hukum maupun media internet yang berkaitan dengan permasalahan dalam penelitian ini. Analisis bahan hukum yaitu apanbila seluruh bahan hukum yang dibutuhkan sudah terkumpul, kemudian penulis menafsirkan atau menginterpretasi secara sistematis dan terstruktur dengan memberikan argument serta solusi terhadap permasalahan kekaburan norma yang disimpulkan dan semuanya dituangkan kedalam karya tulis ilmiah berupa jurnal hukum.

\section{HASIL DAN PEMBAHASAN}

\section{Perlindungan Hukum terhadap Penyandang Disabilitas sebagai Korban Tindak Pidana Perkosaan}

Perlindungan hukum dapat diartikan bahwa segaka upaya untuk menjaga atau melindungi hak dan kewajiban setiap orang melalui peraturan-peraturan hukum yang dimana bertujuan memberikan rasa aman dan menjamin keselamatan setiap orang (Malinda, 2016: 1). Perlindungan hukum dilihat dari suatu ketentuan peraturan yang dibentuk oleh setiap orang berdasarkan persetujuan masyarakat untuk mengatur hubungan perilaku setiap masyarakat atau perseorangan dengan pemerintahan yang dianggap menyertai kepentingan masyarakat. Mengenai masalah perlindungan terhadap seseorang yang menjadi korban tindak pidana berhak terlepas dari kekerasan maupun perlakuan yang bersifat memandang rendah atau membeda-bedakan seseorang atas dasar apapun. Hal ini ditegaskan dalam pasal 28 I Undang-Undang Dasar Negara Republik Indonesia tahun 1945.

Dari pengaturan tersebut dapat dikaitkan dengan perlakuan terhadap penyandang disabilitas dimana para penyandang disabilitas haruslah diberlakukan sama atau setara dihadapan hukum, walaupun dalam hal fisik, intelektual, mental, dan sensorik kurang sempurna dan tidak sama dengan keadaan masyarakat normal pada umumnya. Perlindungan terhadap penyandang disabilitas merupakan upaya yang dilakukan pemerintah untuk melindungi, mengayomi, dan memperkuat hak penyandang disabilitas yang tertuang dalam pasal 3 UU Nomor 8 tahun 2016. Pelanggaran yang kerap diterima oleh para disabiitas yaitu tindak pidana perkosaan.

Mengenai bentuk-bentuk perlindungan yang dapat diberikan kepada penyandang disabilitas sebagai korban perkosaan ada dua bentuk yaitu, pertama adalah restitusi yaitu bentuk ganti rugi, diserahkan kepada korban maupun keluarga korban oleh pelaku, berupa pemberian uang ganti rugi untuk kehilangan ataupun penderitaan, atau penggantian dalam tindakan tertentu. Kedua adalah bantuan medis atau bantuan rehabilitasi yang dimana ditunjukan kepada korban oleh Lembaga Perlindungan Saksi dan Korban (LPSK) guna untuk mengobati luka atau trauma yang dialami korban akibat dari perbuatan tersebut (Waluyo, 2011: 18).

Berdasarkan permasalahan tersebut penulis berpendapat bahwa perlindungan hukum merupakan segala bentuk pengayoman terhadap harkat dan martabat manusia dalam memperoleh pengkuan terhadap hak asasi manusia di bidang hukum. Perlindungan hukum sangat erat kaitannya dengan keadilan. Jadi, perlindungan hukum terhadap penyandang disabilitas sebagai korban tindak pidana perkosaan merupakan kegiatan untuk menjaga atau memelihara para penyandang disabilitas demi mencapai keadilan dan bebas dari tindakan kejahatan. Kemudian perlindungan hukum di konstruksikan sebagai bentuk pelayanan dan subjek yang dilindungi. 


\section{Sanksi terhadap Pelaku Pemerkosaan Penyandang Disabilitas}

Pemerkosaan berdasar dari kata perkosa yang berarti memaksa dengan perkasa atau menggagahkan diri. Perkosa memiliki arti yaitu menundukan seseorangan dengan kekerasan, pemaksaan, atau melalui ancaman kekerasan menyetubuhi seorang wanita. Salah satu bentuk kekerasan terhadap perempuan yang merupakan ancaman bagi para perempuan, khususnya mengenai kepentingan seksual laki-laki. Kepentingan laki-laki tersebut menunjukan adanya ketidak seimbangan gender dimana perempuan harus menghadapi kekerasan, pemaksaan, dan penyiksaan fisik serta psikisnya merupakan tindak pidana perkosaan (Biljana \& Suryana, 2018: 2).

Setiap orang yang melalui kekerasan atau ancaman memaksa seorang wanita berhubungan badan dengannya diluar perkawinan dengan unsur kesengajaan dianggap telah melakukan perbuatan perkosaan yang tertera dalam pasal 285 KUHP. Unsur dari kesengajaan yang dimaksud diatas haruslah dibuktikan oleh penuntut umum maupun oleh majelis hakim dalam ranah persidangan (Lamintang \& Lamitang, 2009: 101). Pelaku tindak pidana perkosaan terhadap perempuan tidak hanya terbatas pada usia, pekerjaan ataupun status sosial melainkan kaum lelaki yang sudah berpengalaman dalam melakukan tindakan perkosaan tersebut.

Mengenai bentuk-bentuk dari tindak pidana perkosaan ada beberapa ragam bentuknya diantaranya yaitu, a) Sadistic Rape yang artinya bentuk perkosaan yang agresif dan bersifat merusak, b) Anger Rape yang biasanya dalam bentuk penganiayaan terhadap korbannya, c) Domination Rape yang dimana perkosaan atas dasar kekuasaan yang dimiliki pelaku untuk memaksa korban, d) Seductive Rape yaitu perkosaan yang terjadi pada situasi pelaku dalam keadaan merangsang yang diciptakan oleh korban maupun pelaku, e) Victim Preciptaited Rape yaitu perkosaan yang diakibatkan oleh korban yang menjadi dalangnya, f) Exploitasi Rape yaitu perkosaan yang menunjukan pada kesempatan diperoleh untuk melakukan perkosaan yang diperoleh laki-laki dengan mengambil keuntungan dari korban (Wahid \& Irfan, 2001: 46).

Pemahaman terhadap pemberian sanksi pidana tidak terpisahkan dari kata pemidanaan. Dimana sanksi pidana merupakan suatu hukum sebab akibat, sebab merupakan suatu tindakaan kejahatan yang dilakukan dan akibat dari kejahatan tersebut menimbulkan sanksi yang bersifat mengikat yang dikenakan terhadap pelaku yang melakukannya. Sanksi pidana terhadap pelaku tindak pidana perkosaan dengan korbannya selaku penyandang disabiitas terdapat dalam kasus yang telah diputuskan oleh Pengadilan Negeri Cirebon dengan Putusan Kasasi Nomor: 736 K/PID/2013 dimana Majelis Hakim menjatuhakan putusan dengan mempertimbangkan pasal 285 KUHP, yang dimana unsur-unsurnya merupakan siapa saja dengan kekerasan atau ancaman kekerasan memaksa seorang perempuan yang bukan isterinya berhubungan badan dengan dia atas dasar tersebut hakim memberikan putusan Menyatakan Terdakwa Yuswadi alian Pepen Bin Samaun terbukti sah dan bersalah melakukan tindak pidana perkosaan kepada korban yang bernama Mimin oleh karena perbuatannya tersebut maka pidana penjara selama 10 (sepuluh) tahun dan menetapkan masa penahanan yang telah ditempuh terdakwa dikurangkan seluruhnya dari pidana yang dijatuhkan.

Dilihat dari penjelasan tersebut penulis memberikan pendapat yaitu, dalam hukum positif di Indonesia. Tindak pidana perkosaan tertuang secara umum dalam UU Nomor 1 Tahun 1946 tentang Kitab Undang-Undang Hukum Pidana yaitu terdapat pada Bab XIV tentang Kejahatan Terhadap Kesusilaan yang lebih lanjut diatur dalam pasal 285 sampai dengan 288 KUHP. Sanksi bagi pelaku tindak pidana perkosaan terhadap para disabilitas lebih merunjuk pada Pasal 285 dan 286 KUHP dimana penyandang disabilitas termasuk kedalam unsur tidak berdaya pada pasal 286 KUHP yang dimana penyandang disabilitas tidak berdaya melawan atau menyelamatkan dirinya karena faktor kekurangan yang mereka miliki.

\section{SIMPULAN DAN SARAN}

\section{Simpulan}

Berdasarkan uraian-uraian di atas, dapat ditarik simpulan untuk menjawab masalah yang terdapat dalam karya tulis ilmiah ini, yaitu:

a. Perlindungan hukum terhadap penyandang disabilitas sebagai korban kejahatan perkosaan harus diawasi atau dilihat karena mereka sangat sensitif terhadap berbagai macam gangguan sosial, mental, dan fisik. Perlindungan terhadap penyandang disabilitas sebagai korban tidak pidana perkosaan ditekankan dalam pasal 5 ayat (2) Undang-Undang Nomor 8 Tahun 1981 tentang Penyandang disabilitas, yaitu: wanita penyandang disabilitas mempunyai hak sebagai berikut : a) 
Hak untuk memiliki keturuan; b) Bebas Menerima atau tidak untuk penggunaan alat kontrasepsi; c) Mendapat pengawasan dari perlakuan kejahatan dalam diskriminasi berlapis; dan d) Berhak mendapatkan perngamanan lebih dari tindak kekerasan, termasuk kekerasan seks. Bentuk perlindungan yang dapat diberikan terhadap penyandang disabilitas sebagai korban tindak pidana perkosaan adalah: 1) Restitusi, yang merupakan ganti kerugian yang diseraahkan kepada korban atau keluarganya oleh pelaku, berupa peengembalian harta milik, pembayaran ganti kerugian mengenai kehilangang atau penderitaan, atau ganti rugi material berupa uang untuk tindakan tertentu yang tertuang dalam Peraturan Pemerintah Republik Indonesia Nomor 44 Tahun 2008 tentang Pemberian Kompensasi, Restitusi, dan Bantuan Kepada Saksi dan Korban; 2) Bantuan Pengobatan dan Bantuan Rehabilitasi; bantuan tersebut merupakan layanan yang diberikan kepada korban dan/atau saksi untuk menjalani pengobatan atau bimbingan oleh Lembaga Perlindungan Saksi dan Korban (LPSK).

b. Sanksi terhadap pelaku pemerkosaan penyandang disabilitas juga terdapat dalam hukum positif di Indonesia. Tindak pidana perkosaan dimuat secara umum dalam UU Nomor 1 Tahun 1946 tentang Kitab Undang-Undang Hukum Pidana yaitu pada Bab XIV tentang Kejahatan Terhadap Kesusilaan yang lebih lanjut diatur dalam pasal 285 sampai dengan 288 KUHP. Pada Putusan Kasasi Nomor 736 K/PID/2013 PN.Cn sanksi bagi pelaku kejahatan perkosaan terhadap seorang disabilitas lebih merunjuk pada Pasal 285 dan 286 KUHP dimana seorang disabilitas termasuk kedalam unsur tidak berdaya pada pasal 286 KUHP yang dimana seorang disabilitas tidak berdaya melawan atau menyelamatkan dirinya karena faktor kekurangan yang mereka miliki.

\section{Saran}

Setelah dilakukan pembahasan sebelumnya, maka penulis mempunyai saran sebagai berikut:

a. Mengenai perlindungan hukum penyandang disabilitas sebagai korban tindak pidana perkosaan perlu adanya penerapan secara instensif dari pemerintah, penegak hukum maupun masyarakat terhadap hak-hak seorang disabilitas, mengingat seorang disabiitas merupakan masyarakat yang memiliki kekurangan dalam hal mental, sensorik, intekektual dan/atau fisik yang kerap mendapatkan perlakuan kurang mengenakan dalam lingkungannya.

b. Mengenai sanksi pidana terhadap pelaku tindak pidana perkosaan penyandang disabilitas perlu adanya penyempurnaan dalam ketentuan Undang-Undang Nomor 8 Tahun 2016 tentang Penyandang Disabilitas berkaitan dengan sanksi pidana bagi pelaku kejahatan perkosaan terhadap penyandang disabilitas dengan tujuan meningkatkan efek jera terhadap para pelaku kejahatan perkosaan tersebut.

\section{DAFTAR PUSTAKA}

Alfian, A. (2015). Perlindungan Hukum terhadap Kaum Difabel Korban Pemerkosaan. Fiat Justisia Jurnal Ilmu Hukum, 9(4), 629-642.

Ayu, R. (2019). Perlindungan Hukum terhadap Penyandang Disabilitas Tunagrahita Korban Tindak Pidana Perkosaan (Studi di Dinas Pemberdayaan Perempuan, Perlindungan Anak dan Masyarakat Kota Binjai). Universitas Muhammadiyah Sumatera Utara.

Biljana, V., \& Suryana, Y. (2018). Tinjauan Psikologis Hukum dalam Perlindungan Anak. CV Budi Utama.

Hamzah, A. (2015). Delik-Delik Tertentu (Speciale Delicten) di dalam KUHP. Sinar Grafika.

Lamintang, P. A. ., \& Lamitang, T. (2009). Delik-Delik Khusus: Kejahatan Melanggar Norma Kesusilaan \& Norma Kepatuhan. Sinar Grafika.

Malinda, A. (2016). Perempuan dalam Sistem Peradilan Pidana. Garudhawaca.

Malinda, A., Nurfitriana, E., \& Arif, M. Y. Al. (2014). Bantuan Hukum terhadap Kaum Difabel Korban Tindak Pidana Upaya Mewujudkan Acces to Justice. Jurnal Hukum Ius Quia Iustum, 21(3), 465-484.

Nurhayati, S. (2016). Kesetaraan di Muka Hukum bagi Penyandang Disabilitas. Jurnal Realita, 14(1), 94-110.

Wahid, A., \& Irfan, M. (2001). Perlindungan terhadap Korban Kekerasan Seksual, Advokasi atas Hak Asasi Perempuan. PT. Refika Aditama.

Wahyuni, F. (2016). Sanksi Pidana Pemerkosaan terhadap Anak Menurut Hukum Pidana Positif dan Hukum Pidana Islam. Jurnal Media Hukum, 23(1), 95-109. 
Jurnal Konstruksi Hukum

Vol. 1, No. 1, 2020

Waluyo, B. (2011). Viktimologi Perlindungan Korban \& Saksi. Sinar Grafika. 